\title{
IMPLEMENTASI METODE SUZUKI DALAM PEMBELAJARAN BIOLA TINGKAT DASAR DI ERA MUSIKA MEDAN
}

\author{
Arga Novia Bernadetta S. \\ bernadettanovia@gmail.com
}

\begin{abstract}
This study aims to describe the implementation of basic level violin learning using the Suzuki method in the Medan Musika Era. The subjects in this study were students who took violin instruments in the Medan Musika Era. This study focused on the problems associated with the implementation of basic level violin learning with the Suzuki method, which was viewed from the process of the steps of the study. This study used descriptive qualitative research methods, namely a research method that aims to describe in detail and clearly about a phenomenon which is the focus of research. The results of the research on the implementation of basic level violin learning using the Suzuki method in the Medan Musika Era show as follows (1) Education 'starts at a very early age by not limiting students who learn violin in the Musika Era. (2) Prioritizing to teach students to listen to just play a musical instrument, by the way the teacher demonstrates the song learned by the new student, the student mimics the song. (3) Violin learning takes place by giving songs that are in Suzuki's books repeatedly. (4) Learning to read beam notation using fingering in accordance with what is in the Suzuki method book.
\end{abstract}

Key Words: implementation, method, learning

\section{Pendahuluan}

Biola belakangan ini menjadi alat musik klasik yang mulai digemari kaum awam dan ditandai dengan meningkatnya permintaan pembelajaran tingkat pemula, ini dilihat dari data di beberapa lembaga musik yang ada di kota Medan menyatakan bahwa semakin meningkatnya siswa yang mendaftar untuk belajar instrument biola. Menurut pengalaman saya sebagai pengajar biola peminat instrument biola pemula kebanyakan langsung pesimis dalam mempelajari instrumen yang satu ini. Murid masih menganggap belajar biola sangat sulit. Hal ini terjadi di beberapa lembaga musik di Medan, seperti di Chieke Musik, Kusuma Widjaja Music, Era Musika Medan dan lain sebagainya.
Seiring meningkatnya peminat instrument biola pemula tentu perlu pengembangan di berbagai aspek untuk meningkatkan kualitas. Menurut pengalaman saya sebagai pengajar biola perlu diadakannya pelatihan rutin untuk guru, pembangunan perpustakaan, perbaikan media pembelajaran. Itu merupakan salah satu cara untuk meningkatkan kualitas dalam pembelajaran, selain itu pengembangan metode dalam pembelajaran merupakan hal yang penting untuk keberhasilan dari suatu pembelajaran.

Penggunaan metode yang tepat sangat berpengaruh pada keberhasilan serta tujuan yang akan dicapai dari proses belajar mengajar tersebut. Metode pembelajaran merupakan salah satu dari komponenkomponen utama yang berpedoman pada kurikulum. 
Salah satu pendekatan metode pembelajaran musik yang sudah dilakukan dan diterapkan bagi siswa adalah metode Suzuki.Metode Suzuki adalah metode mengajar khusus untuk menuntun dari tingkat yang sangat dasar sampai tingkat lanjut. Metode ini dipakai sangat luas dalam permainan biola, dan metode yang sama juga diterapkan pada instrumen lain seperti piano,flute, dan lainnya. Metode Suzuki ini merupakan salah satu metode yang dikenal di lingkungan musik.

Maka tujuan yang hendak dicapai oleh si peneliti adalah Untuk mengetahui bagaimana Implementasi Metode Suzuki dalam pembelajaran Biola tingkat dasar di Era Musika Medan, Untuk mengetahui proses pembelajaran biola tingkat dasar menggunakan metode suzuki di Era Musika Medan, Untuk mengetahui apa saja kesulitan didalam pembelajaran biola tingkat dasar menggunakan metode suzuki di Era Musika Medan

Metode Suzuki menggunakan pendekatan pendidikan instrument musik (instrumental music education) yang mengacu kepada filosofi pendidikan dan pengajaran dari Shinichi Suzuki. Shinichi mulai mengembangkan metode pendidikan musiknya pada tahun 1931-an, berdasarkan pemahamannya pada kemampuan proses belajar anak kecil. Metode ini juga dikenal sebagai "Mother Tongue Approach" terinspirasi dari prinsip dasar pembelajaran bahasa ibu, dimana Shinichi menyadari implikasi fakta bahwa anak-anak dapat mempelajari bahasa ibu mereka tanpa kesulitan sedikitpun. Prinsip inilah yang akan diaplikasikan dalam pembelajaran biola (Shinichi suzuki, 1984:2).

Metode ini menitik beratkan pentingnya pengaruh dan keterlibatan orang tua sebagai "guru di rumah" bagi sang buah hati dan sebagai "partner" dengan guru untuk menciptakan lingkungan belajar yang menyenangkan bagi sang anak. Oleh karena dua hal ini, maka dalam metode ini orang tua diharapkan untuk hadir dalam pelajaran musik untuk mengobservasi, mengetahui perkembangan anak, bagaimana tips cara berlatih yang baik, apa saja yang perlu diperhatikan dalam latihan sehari-harinya, dan menjalin komunikasi yang baik dengan guru di kelas. Keterlibatan orang tua merupakan salah satu faktor yang mendukung perkembangan anak, dan secara tidak langsung orang tua juga belajar untuk mendidik anaknya. Dalam metode Suzuki ditanamkan konsep: Pertama karakter (Character First) dan kedua kemampuan (Ability Second). Tujuannya adalah untuk merangkul seluruh anak, memupuk rasa cinta terhadap musik, dan pengembangan karakter yang baik, bukan hanya sekedar penguasaan instrumen musik. Ide inilah yang dikenal sebagai "Talent Education" atau pendidikan bakat (Shinichi Suzuki, 1984:6).

Pendidikan bakat ini tidak
hanya pengembangan keterampilan kemampuan saja, melainkan juga pengembangan karakter atau pribadi seseorang, dan peningkatan kemampuan orang berfikir. Tujuan dari pendidikan bakat ini bukan hanya untuk menciptakan musisi professional., melainkan menciptakan musisi yang baik. Melalui musik, 
anak akan menunjukkan kemampuan yang luar biasa dalam semua bidang yang mereka tekuni dan menjadi manusia yang lebih baik (Shinichi Suzuki, 1984:9).

Dalam metode Suzuki ini juga terdapat konsep-konsep teknik, dasardasar musik, dan repertoar dalam urutan yang logis. Metode Suzuki pertama kali diperkenalkan di Jepang di sekolah Matsumoto, dan berkembang ke Amerika sekitar tahun 1960-an, kemudian ke Eropa, Asia, dan negara-negara lainnya. Meskipun pada awalnya metode ini dikembangkan untuk instrument biola, tetapi sekarang telah dapat diaplikasikan untuk instrumen musik lainnya, seperti: piano, cello, flute, gitar, dan instrument lainnya. Selain itu juga ada "Suzuki prasekolah" yang telah diadaptasi dari filosofi Suzuki untuk digunakan dalam non-musik disiplin pendidikan anak usia dini. Saat ini ada lebih dari 8000 guru di seluruh dunia yang lebih dari 250.000 anak-anak yang mempelajari metode Suzuki.

Metode Suzuki berawal dari pengamatan Shinichi terhadap anakanak dalam mempelajari bahasa ibu mereka tanpa kesulitan yang berarti. Ia menyadari bahwa anak-anak yang lahir dalam lingkungan yang berbahasa Jerman dapat mempelajari bahasa Jerman secara alami, dimana anak-anak belajar melalui pengamatan mereka sendiri terhadap lingkungan di sekitar mereka. Begitu pula di Jepang, anak-anak di Jepang dapat secara alami beradaptasi untuk berbicara dalam bahasa ibu mereka tanpa pendidikan formal, padahal bahasa Jepang merupakan salah satu bahasa yang kompleks (Shinichi Suzuki, 1984:2).
Didalam Metode Suzuki ada beberapa elemen dasar didalam pembelajaran antara lain adalah sebagai berikut :

a. Musik yang berkualitas diawali sejak lahir

Semakin dini murid diperkenalkan kepada anak, semakin tinggi pula tingkat perkembangan indera pendengarannya (aural sense) dan kemampuan dalam menangkap, menyerap unsur/bahasa musik dan bermain musik

\section{b. Permulaan}

Dalam Metode Suzuki, pendidikan musik harus dimulai dari usia yang sangat dini, ketika otak anaknak dapat menyerap dan menangkap musik dengan sangat cepat (golden age), supaya terciptalah sebuah proses mental dan koordinasi otot yang baik. Beliau menyarankan, agar anak-anak dapat bermain musik setiap hari.

c. Peran dan keterlibatan

Seperti pada saat anak belajar berbicara, orang tua selalu terlibat dalam pembelajaran musik anaknya. Orang tua akan menghadiri kelas dengan anaknya, serta bertindak sebagai "guru di rumah". Bahkan tidak jarang orang tua juga ikut mempelajari instrumen musik sebelum anak-anak mereka mempelajari instrumen tersebut, supaya orang tua memahami apa yang anak mereka harus lakukan. Anakanak akan menghabiskan waktu lebih banyak bersama dengan orang tua yang akan membantu mereka berlatih. Guru akan mengarahkan orang tua untuk menciptakan lingkungan belajar yang positif di rumah sehingga anak dapat belajar dengan mudah tanpa dipaksa. Ketika konsentrasi 
anak meningkat, maka waktu latihan anak dapat diperpanjang.

d. Adaptasi terhadap alat musik sebelum belajar membaca musik

Anak-anak tidak diajarkan untuk membaca sebelum mereka memiliki kemampuan untuk berbicara. Dibutuhkan waktu yang lama dan latihan yang teratur bagi anak-anak untuk menyamai kemampuan membaca mereka dan kemampuan berbicara mereka. Oleh karena itu, dalam Metode Suzuki membaca not belum dimulai sebelum anak mengenal instrumen musik yang ia mainkan. Yang terpenting disini adalah telinga yang mendahului mata. Murid-murid yang mempelajari musik lewat Metode Suzuki dapat membaca dengan baik karena telinga mereka sudah berkembang dengan baik pula, sehingga simbol-simbol musik yang tertulis telah terekam dalam ingatan mereka sebagai sebuah bunyi yang berarti untuk mereka. Membaca sebaiknya dilakukan dengan cara yang sama seperti halnya bagaimana kemampuan bermain musik berkembang, yaitu dengan cara yang logis dan melalui pengulangan, ditunjang penguasaan kemampuan yang lain, dan disesuaikan dengan kondisi atau kemampuan murid.

\section{e. Bermain dengan mengingat} Ketika anak-anak terus memainkan lagu-lagu yang dapat dimainkan, maka anak-anak akan terdorong untuk mendengarkan kualitas nada yang mereka hasilkan, apakah sudah baik atau belum.

f. Pengulangan yang konstruktif Pengulangan merupakan hal yang penting dalam belajar memainkan instrumen. Seseorang tidak hanya sekedar mempelajari sebuah kata atau lagu. Mereka menambahkan kata-kata itu ke dalam perbendaharaan kata mereka (vocabulary) atau repertoire secara perlahan-lahan, dan dengan cara yang baru dan lebih baik dari sebelummya. Dengan mengulang, kemampuan bertambah, teknik bermain semakin mahir, dan kemampuan bermusik semakin meningkat pula.

g. Kombinasi antara pelajaran privat dan grup

Semua siswa (tidak terbatas oleh umur) didorong untuk bermain bersama di dalam sebuah kelompok untuk menciptakan semangat bekerjasama (cooperation) yang baik dan bergembira (fun). Melihat anakanak lain bermain lagu yang sama di dalam kelompok akan memotivasi anak untuk dapat belajar dan bermain bersama seperti teman-temannya yang lainnya. Disini terjadilah suatu pembelajaran yang alami.

h. Pertunjukan publik

Mendengarkan anak-anak lain dalam sebuah konser akan menstimulasi anak supaya lebih tertantang untuk melakukan hal yang lebih baik dari orang lain. Semakin sering hal ini dilakukan maka semakin antusias anak ingin mempelajari musik yang mereka dengarkan dan memainkan lagu tersebut. walaupun lagu itu merupakan lagu yang sulit sekalipun. Hal ini akan memotivasi anak untuk terus tekun berlatih dan memiliki tujuan jangka panjang. Seseorang yang memiliki motivasi yang tinggi tidak akan pernah merasa sulit dalam mempelajari suatu hal yang baru.

i. Mendengarkan

Anak-anak mempelajari katakata setelah mendengarkan kata-kata 
tersebut diulang beberapa ratus kali oleh orang lain. Ketika anak mulai mempelajari instrumen musik, mendengarkan merupakan hal utama yang harus dipelajarinya. Mendengarkan lagu lewat compact disc atau kaset merupakan hal yang harus dilakukan setiap hari. Dengan mendengar, anak akan mampu mempelajari bahasa musik (language of music) dan mengembangkan indera pendengarannya terhadap musik (musical ear). Semakin cepat seorang anak diperkenalkan kepada musik, maka semakin besar pula kesempatan untuk mengembangkan indera pendengaran, teknik bermain, dan kemampuan bermusik yang sempurna.

\section{j. Pemberian semangat}

Seperti layaknya bahasa, usaha anak dalam mempelajari instrumen sebaiknya disertai dengan pujian dan dorongan yang positif, untuk menciptakan sikap yang positif dalam belajar, saling men-support dan kerjasama (cooperation) yang baik dalam sebuah kelompok. Motivasi dalam Metode Suzuki merupakan hal yang tidak sulit dilakukan, karena murid-murid Suzuki mendapatkan banyak kesempatan untuk berbaur bersama siswa-siswa lainnya dalam group lesson, workshop, dan konser. Jadi dapat dirangkumkan bahwa Metode Suzuki adalah metode yang sangat praktis dan efisien untuk pembelajaran biola tingkat pemula, dikarenakan didalam Metode Suzuki ini peserta didik dibimbing dari sangat dasar, seperti mengenal biola terlebih dahulu, postur tubuh yang baik dan lagu lagu yang terdapat di dalam buku Suzuki ini sangat bervariasi dan cocok bagi pemula.
Metode Suzuki menuntut beberapa kemampuan diri antara lain: kedisiplinan, ketenangan, percaya diri, disamping itu juga postur tubuh yang baik, penguasaan teknik bermain, dan juga peran serta orang tua dan motivasi sangat penting untuk peserta didik agar terus ingin belajar lagi.

Pada penelitian ini, peneliti menggunakan metode penelitian kualitatif. Hal ini dimaksudkan untuk menggali data yang masih ada untuk memperoleh informasi yang diperlukan dalam penelitian

Menurut Ary, dkk (2010:221) menyatakan bahwa:"A population is difined as all members of any well difined class of people, events, or objects." Atau,"The larger group about which the generalization is made is called a population." Artinya, bahwa populasi itu merupakan kelompok yang lebih besar jumlahnya dan biasanya yang dipakai untuk menggeneralisasi hasil peneitian. Sedangkan menurut Wiratna Sujarweni (2014:65) menyatakan bahwa: "Populasi adalah keseluruhan jumlah yang terdiri atas objek atau subjek yang mempunyai karakteristik dan kualitas tertentu yang ditetapkan oleh peneliti untuk diteliti dan kemudian ditarik kesimpulannya".

Berdasarkan pendapat diatas, maka yang menjadi populasi dalam penelitian ini adalah Yayasan Era Musika Medan.

Menurut Wiratna Sujarweni (2014:65) menyatakan bahwa:

"Sampel adalah

bagian dari sejumlah karakteristik yang dimiliki oleh populasi yang digunakan untuk 


$\begin{array}{lr}\text { penelitian. } & \text { Bila } \\ \text { populasi } & \text { besar, } \\ \text { peneliti } & \text { tidak } \\ \text { mungkin } & \text { mengambil } \\ \text { semua } & \text { untuk } \\ \text { penelitian } & \text { misal } \\ \text { karena terbatasnya } \\ \text { dana, tenaga, dan } \\ \text { waktu,maka peneliti } \\ \text { dapat menggunakan } \\ \text { sampel yang diambil } \\ \text { dari populasi. } \\ \text { Berdasarkan pendapat diatas } \\ \text { menjadi sampel dalam } \\ \text { ian ini 5 siswa dan 2 guru Era } \\ \text { Medan yang mengambil } \\ \text { ntrasi intrumen biola. }\end{array}$

Sesuai dengan judul penelitian "Implementasi Metode Suzuki Dalam Pembelajaran Biola Tingkat Dasar Di Era Musika Medan", maka lokasi penelitian ini dilakukakan di Era Musia Medan. Waktu yang digunakan dalam pelaksanaan penelitian ini terhitung selama 2 bulan dimulai dari Agustus 2018 sampai dengan September 2018.

Didalam seluruh rangkaian penelitian ini, peneliti menggunakan teknik pengumpulan beraneka ragam data dalam berbagai bentuk. Teknikteknik pengumpulan data yang akan digunakan peneliti adalah:

1. Observasi

Dalam melakukan sebuah penelitian, peneliti wajib mengikuti tata cara yang telah ditetapkam, salah satunya ialah observasi. Obervasi adalah pengamatan dan pencatatan yang sistematis terhadap gejala-gejala yang diteliti, observasi menjadi salah satu teknik pengumpulan data apabila sesuai dengan tujuan penelitian, direncanakan secara sistematis. Menurut Wiratna Sujarweni (2014:75) menyatakan bahwa:
“Observasi adalah pengamatan secara sistematik terhadap gejala yang tampak pada objek penelitian."

Dalam melakukan observasi lapangan, peneliti meninjau, mengamati, menyimpan, dan memahami tentang data akurat tentang Implementasi Metode Suzuki Dalam Pembelajaran Biola Tingkat Dasar Di Era Musika Medan

2. Wawancara

Wawancara digunakan sebagai teknik pengumpulan data apabila peneliti ingin melakukan studi pendahuluan untuk menemukan permasalahan yang harus diteliti, dan juga apabila peneliti ingin mengetahui hal-hal dari responden yang telah mendalam dan jumlah respondennya sedikit/kecil. Menurut Wiratna Sujarweni (2014:74) menyatakan bahwa: "Wawancara adalah salah satu instrumen yang digunakan untuk menggali data secara lisan."

Sesuai dengan teknik wawancara, penulis melakukan wawancara dengan guru biola di Era Musika Medan

3. Dokumentasi Menurut Sugioyono (2017:240) yang mengatakan: "Dokumentasi merupakan catatan peristiwa yang telah berlalu. Dokumentasi bias berbentuk tulisan, gambar atau karya-karya monumental dari seseorang". Untuk melengkapi isi laporan ini agar lebih sempurna, peneliti tidak hanya menggunakan data-data tertulis tetapi juga menggunakan dokumentasi sebagai alat bantu dilapangan ketika sedang melaksanakan observasi dan wawancara. Dokumentasi digunakan untuk mendapatkan data tentang 
bagaimana implementasi metode suzuki dalam pembelajaran biola tingkat dasar di era musika Medan. Teknik dokumentasi dapat menguatkan data-data yang diperoleh melalui observasi dan wawancara. Studi dokumentasi ini dilakukan untukmendapatkan foto-foto, video, dan beberapa dokumen yang dimilik pihak Era Musika Medan yang berhubungan dengan kegiatan proses pembelajaran biolaberlangsung.

Penelitian ini meggunakan teknik analisis data kualitatif yang terkumpul melalui observasi, wawancara, dokumentasi dan studi kepustakaan. Teknik analisis data dalam penelitian ini akan diupayakan untuk menjawab keseluruhan pertanyaan penelitian. Disisi lain langkah ini dapat menjadi bahan koreksi tehadap berbagai kekurangan data yang terkumpul sehingga untuk selanjutnya dilengkapi. Setelah seluruh data selesai dikumpulkan dari lokasi penelitian, maka tahap akhir dari penelitian ini adalah mendeskripsikan dan menganalisis keseluruhan data-data dalam bentuk tulisan ilmiah untuk menemukan beberapa kesimpulan yang dapat menjawab seluruh pertanyaan penelitan.

\section{Isi}

Proses pembelajaran biola dengan Metode Suzuki di Era Musika Medan dilakukan dalam 4 kali pertemuan. Pada setiap pertemuan tersedia waktu pembelajaran selama 30 menit.

\section{Penyeteman (Tuning) \\ Penyeteman dilakukan}

oleh pengajar karena murid masih kesulitan untuk melakukan penyeteman secara mandiri.
Penyeteman dilakukan pada senar $\mathrm{G}$, D, A, E, biasanya pengajar menggunakan alat tuning yang disebut tuner untuk menyetem nada $\mathrm{A}$, atau untuk menentukan nada $\mathrm{A}$ pengajar menggunakan biola pengajar yang sudah disetem terlebih dahulu.

\section{Pemanasan}

$$
\text { Pemanasan dilakukan }
$$

selama 10-15 menit dalam setiap pertemuan, ini bertujuan agar murid terbiasa dalam menggesek dan membiasakan penjariannya.

3. Pembelajaran materi

Proses pembelajaran materi dilakukan dengan bebarapa tahap yaitu membaca lagu secara utuh, dipelajari setiap bagian, pengenalan dinamik, penyempurnaan lagu dan penugasan.

$$
\text { a. Membaca notasi lagu secara }
$$

utuh

Siswa yang mendapat materi lagu, diajarkan dengan membaca notasi lagu

secara utuh dari awal sampai akhir lagu. Dalam proses ini siswa hanya membaca nada saja menggunakan penjarian saja belum mengenal dinamik dan penguasaan

lagu dengan benar. Proses ini dimaksudkan agar siswa dapat mengenal terlebih dahulu nada-nada yang ada dalam lagu tersebut. Proses ini dilakukan pada pertemuan awal pemberian materi.

b. Mempelajari lagu perbagian 
Materi lagu yang dipelajari siswa diajarkan oleh guru dengan cara melatih setiap bagian frase lagu yang dipelajari secara mengulang terus menerus (drill). Proses ini dimaksudkan agar siswa mempelajari lagu tersebut dengan detail setiap frasenya dan lancar membaca notasi lagu yang sedang dipelajari baik secara ritmis

dan dinamik serta teknik yang dimainkan.

Berdasarkan penelitian pada bulan Agustus sampai Oktober 2018 di Era Musika Medan, diperoleh data mengenai Implementasi Metode Suzuki di Era Musika Medan yang dilakukan guru kepada siswa dalam proses pembelajaran biola tingkat dasar. Berikut beberapa implementasi Metode Suzuki yang dilakukan oleh guru di Era Musika Medan dalam proses pembelajaran biola tingkat dasar yaitu:

1. Pendidikan diawali dengan usia dini.

Pembelajaran biola di Era Musika Medan menekankan pendidikan usia dini sesuai dengan Implementasi yang ada didalam Metode Suzuki dalam bukunya Ability Development From Age Zero. Hal tersebut terbukti penerimaan siswa di Era Musika Medan tidak membatasi umur siswanya. Hal tersebut terbukti banyak Siswa yang masuk di berumur 5-10 tahun. Walaupun demikian tidak semua diawali diusia sangat dini ada juga diantaranya siswa yang belajar di
Era Musika Medan dimulai saat mereka sudah menduduki bangku sekolah SMP dan SMA.

2. Pembelajaran materi lagu metode Suzuki.

Di dalam Metode Suzuki pembelajaran musik diawali dengan memainkan satu lagu secara diulangulang beberapa bulan kemudian dapat ditambah lagu-lagu lain. Pembelajaran biola berlangsung dengan memberikan lagu yang ada di dalam buku Suzuki dan mengajarkan secara berulang-ulang sampai peserta didik dapat dengan baik memainkan lagu tersebut.

Dalam pemberian materi lagu setiap siswa berbeda-beda. Tergantung dari

kemampuan dan minat siswa dalam belajar serta seberapa lama siswa tersebut belajar biola. Sebagai contoh, siswa yang bernama Vison sudah les di Era Musika Medan selama 8 bulan dengan semangat dan keseriusannya ia sudah bisa memainkan lagu Gavotte karya J.S Bach dibuku Suzuki 1. Berbeda dengan Son yang sudah belajar di Era Musika Medan 8 bulan, tapi hanya bisa memainkan lagu May Song didalam buku Suzuki 1.

Berdasarkan wawancara dengan Pak Juriattman selaku guru Biola di Era Musik Medan pada tanggal 22 September 2018, mengatakan bahwa pemilihan Metode Suzuki dikarenakan metode tersebut sangat terkenal dan lagu-lagu yang 
ada di di dalamnya digemari oleh sebagian besar siswa. Selain di digemari lagu di dalam buku Suzuki lebih singkat dan mempermudah untuk siswa belajar biola. Tahapan dalam buku Suzuki sudah sangat jelas, diawali dengan lagu yang termudah hingga menujum ke lagu yang lebih sulit. Dalam Metode Suzuki juga menggunakan penjarian dalam membawa notasi balok, sehingga mempermudah siswa dalam membaca notasi yang ada di dalam lagu yang sedang dipelajari.

Dari hasil penelitian yang ada di Era Musika Medan setiap siswanya mempunyai materi yang berbeda, namun materi yang diberikan sesuai dengan yang ada di dalam buku metode Suzuki. Berikut ini namanama siswa beserta materi yang sedang dipelajari:

\section{Vio}

(May

Song Suzuki 1)

2. Son

(Allegreto Suzuki 1)

\section{Vison}

(Gavotte Suzuki 1)

4. Abigail

(Pengenalan
senar dan lagu
Twingkle-twingkle
little

star )

karena siswa tersebut baru mengikuti

$$
\begin{aligned}
& \text { pembel } \\
& \text { ajaran selama } \\
& 2 \text { bulan dan }
\end{aligned}
$$

umurnya baru

6

\section{Nooren}

Metode Suzuki pada prinsipnya mendasarkan pengajaran pada anak yang

ingin belajar musik, sehingga anak dapat bermain sambil belajar musik. Selain

bermain dan belajar musik, anak juga dapat melatih daya ingat seperti menyanyikan lagu atau dengan tepuk tangan.

Pembelajaran biola menggunakan Metode Suzuki menjelaskan tahap pembelajaran biola dari yang paling mendasar, seperti cara memgang bow, cara menggesek, dan pola-pola penjarian atau teknik fingering. Tangan kanan sangat penting kaitannya dengan kualitas suara yang dihasilkan, sehingga tangan kanan harus benar dalam memegang bow. Sedangkan untuk tangan kiri, membantu membentuk pola-pola penjarian. Berdasarkan dari penerapan metode Suzuki tersebut akan dicapai beberapa penguasaan teknik diantaranya: teknik detache, staccato, legato, penguasan lagu, dan penguasaan ritme. Diharapkan murid dapat

aktif dan dapat melanjutkan belajar biola dengan teknik-teknik tersebut.

\section{Penutup}

Beberapa kesimpulan dapat ditarik bahwa di dalam proses pembelajaran biola di Era Musika Medan tidak sepenuhnya menerapkan metode Suzuki, itu terbukti tidak adanya CD materi pembelajaran dalam proses pembelajaran berlangsung dan pembelajaran kelompok yang tidak ada serta peran orang tua yang kurang aktif. 
Namun penerapannya sudah mengacu pada penerapan yang dilakukan Metode Suzuki. Penerapan Sanggar Bunga Musika dengan metode Suzuki yaitu :

1. Pendidikan dimulai diusia dini dengan cara tidak membatasi siswa yang belajar

biola di Era Musika Medan

2. Mendahulukan mendengar musik baru memainkan alat musik, dengan cara

guru mendemonstrasikan lagu yang dipelajari dilanjutkan siswa menirukan lagu

tersebut kemudian membaca notasinya.

3. Setiap materi diajarkan dengan berulang-ulang agar siswa lancar memainkan

lagu yang dipelajari.

4. Pembelajaran membaca notasi balok menggunakan penjarian sesuai yang

ada di dalam buku Metode Suzuki sehingga siswa lebih mudah mempelajari

lagu yang sedang dipelajaran.

5. Proses pembelajaran biola di Era Musika Medan menggunakan beberapa

tahapan yaitu diawali dengan penyelarasan nada, latihan tangga nada, latihan

teknik, pembelajaran menuju materi lagu dan evaluasi.

Kendala-kendala yang dihadapi dalam Implementasi Metode Suzuki Pada Pembelajaran Biola Tingkat Dasar Di Era Musika Medan adalah :

1. Banyak siswa yang tidak latihan biola ketika dirumah, mengakibatkan kurang dikuasai siswa pada waktunya.
2. Belum menggunakan CD materi pembelajaran Metode Suzuki pada saat proses

belajar mengajar

3. Orang Tua kurang berperan aktif dalam pembelajaran musik anaknya dan

seharusnya orang tua menjadi "guru dirumah"

4. Untuk siswa tingkat dasar penggunaan jari 4 masih sangat sulit

\section{DAFTAR PUSTAKA}

Suzuki. Shinichi. 1984. Nurtured By

Love. USA: Nineteenth Printing

Suzuki. Shinichi 1981. Ability

Development From Age Zero. USA:

Nineteenth Printing

Herfurth. Paul 2003. A Tune A Day.

Boston Musik

Suzuki. Shinichi. 2008. Suzuki Violin

Book 1 USA: Nineteenth Printing

Sumber Jurnal:

Martopo. Hari. 2005. Musik Sebagai

Faktor Penting Dalam Penerapan

Metode

Pembelajaran Quantum. Yogyakarta.

Harmonia: Jurnal Pengetahuan dan

Pemikiran Seni Vol.VI No.2/Mei-

Agustus 2005 